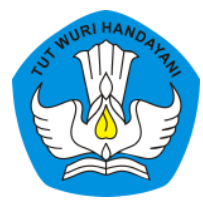

Page: 567-586

\title{
PEMANFAATAN TABEL 3X3 UNTUK MENINGKATKAN PEMAHAMAN KONSEP PEMFAKTORAN KUADRAT
}

\author{
Agus Prianto \\ Sekolah Menengah Pertama Negeri 1 Jepara, Jawa Tengah, Indonesia \\ Contributor Email: agus.mumtaz@yahoo.co.id
}

Received: Mar 12, 2021

Accepted: Jun 6, 2021

Published: Jul 30, 2021

Article Url: https://ojsdikdas.kemdikbud.go.id/index.php/didaktika/article/view/401

\begin{abstract}
The use of Table $3 X 3$ is one way that mathematics teachers can make it easy for students to understand the quadratic factoring concept. The aim of this research is to describe the learning process using Table $3 X 3$ which can improve the understanding of the quadratic factoring concept of class VIII G students of SMP Negeri 1 Jepara. This research is a classroom action research which is carried out in two cycles. Each cycle consists of four components, namely: planning, action, observation, and reflection. The results showed that the use of Table $3 X 3$ can improve understanding of the quadratic factoring concept as indicated by an average test score of 16.39 or $24.38 \%$ in end cycle, from an average score of 67.29 in the first cycle to 83,68 in the second cycle and the achievement value of 75 is from $58.33 \%$ in the first cycle to $72.22 \%$ in the second cycle. Thus it can be concluded that the use of Table $3 X 3$ can improve the understanding of the quadratic factoring concept.
\end{abstract}

Keywords: Mathematics; 3X3 Table; Concept Understanding; Quadratic Factoring 


\begin{abstract}
Abstrak
Pemanfaatan Tabel 3 X3 merupakan satu cara yang dilakukan guru matematika agar siswa mudah memahami konsep pemfaktoran kuadrat. Tujuan penelitian ini adalah mendeskripsikan proses pembelajaran dengan pemanfaatan Tabel 3X3 yang dapat meningkatkan pemahaman konsep pemfaktoran kuadrat siswa kelas VIII G SMP Negeri 1 Jepara. Penelitian ini merupakan penelitian tindakan kelas yang dilaksanakan sebanyak dua siklus. Setiap siklus terdiri dari empat komponen, yaitu: planning, acting, observing, dan reflecting. Hasil penelitian ini menunjukkan bahwa pemanfaatan Tabel 3X3 dapat meningkatkan pemahaman konsep pemfaktoran kuadrat yang ditunjukkan dengan rata-rata nilai tes sebesar 16,39 atau 24,38\% pada akhir siklus yaitu dari rata-rata skor 67,29 pada siklus I naik menjadi 83,68 pada siklus II dan kenaikan ketercapaian nilai 75 yaitu dari 58,33\% pada siklus I menjadi $72,22 \%$ pada siklus II. Dengan demikian dapat disimpulkan bahwa pemanfaatan Tabel 3X3 dapat meningkatkan pemahaman konsep pemfaktoran kuadrat.
\end{abstract}

Kata Kunci: Matematika; Tabel 3X3; Pemahaman Konsep; Pemfaktoran Kuadrat

\title{
A. Pendahuluan
}

Dalam belajar matematika perlu ditekankan tentang pemahaman suatu konsep matematika (conceptual understanding). Hal ini dikarenakan pemahaman suatu konsep merupakan hal yang mendasar dan esensi dalam belajar matematika (Van de Walle, Karp \& Bay-Williams, 2008 \& Zerpa, Kajander dan Van Barneveld, 2009). Beberapa keuntungan bagi siswa jika dapat memahami suatu konsep matematis secara mendalam yaitu: (1) mampu mengemukakan ide, gagasan dan dugaannya sendiri, (2) dapat menggunakan strategi informal untuk menyelesaikan permasalahan, dan (3) dapat saling mengevaluasi hasil pemikiran siswa lainnya (NCTM, 2000: 21). The National Council of Teachers of Mathematics (NCTM) (2000) menjelaskan indikator pemahaman suatu konsep dalam matematika yaitu (1) kemampuan mendeskripsikan dan merepresentasikan konsep dengan bahasa sendiri; (2) kemampuan mengidentifikasi, memberi contoh dan bukan contoh konsep; dan (3) kemampuan menggunakan suatu konsep dengan benar dalam berbagai situasi. 
Menurut Zerpa, Kajander dan Van Barneveld (2009) tingginya tingkat pemahaman konseptual matematika adalah hal penting untuk belajar matematika dengan pemahaman yang mendalam. Woods \& Barrow (dalam Yoong, 1987: 45) menyebutkan pemahaman (understanding) terdiri atas "knowing that", "knowing how" dan "knowing why". Pada konteks matematika "knowing that" berkaitan dengan pengetahuan tentang fakta, konsep, dan prinsip, untuk "knowing how" berkaitan dengan keterampilan, yaitu operasi dan prosedur. Untuk "knowing why" merupakan pembenar dan pembukti "that" dan "how". Skemp (dalam Yoong, 1987: 45-46) menjelaskan bahwa "knowing what to do without reasons" sebagai pemahaman instrumental (instrumental understanding), sedangkan "knowing what to do and why" sebagai pemahaman relasional (relational understanding).

Untuk memperoleh pemahaman konsep (conceptual understanding) baru secara mendalam, maka siswa harus berusaha aktif dan konstruktif melalui pengaitan satu konsep dengan konsep lain yang dilakukan dari siswa sendiri (Subanji, 2015). Keaktifan siswa membangun pengetahuan sendiri merupakan prinsip pembelajaran matematika (NCTM, 2000:20). Keaktifan siswa mengonstruksi permasalahan merupakan syarat agar konsep yang dipelajari dapat dipahami dan memperoleh pengetahuan baru secara menyeluruh, mendalam dan tak mudah terlupakan (Erwin, 2012). Teori konstruktivisme menjelaskan bahwa pengetahuan dan pemahaman bukan datang dari luar melainkan sesuatu yang harus dikonstruksi secara personal dan sosial, dan pada dasarnya setiap siswa pasti mempunyai seperangkat pengetahuan dan pengalaman yang telah diperoleh (Rosalin, 2008: 7). Oleh sebab itu, peran guru selama pembelajaran matematika seyogyanya bukan sebagai "memberi" pengetahuan kepada siswa, tetapi "memfasilitasi" siswa untuk belajar (Subanji, 2013: 84). Guru juga harus memastikan bahwa proses pembelajaran yang terjadi di kelas dapat berjalan baik dan kondusif (Hudojo, 2005: 10).

Pembelajaran materi pemfaktoran kuadrat belum berjalan baik, efektif dan sesuai harapan. Proses pembelajaran didominasi guru sebagai 
pemberi pengetahuan, dan siswa sebagai objek penerima pengetahuan. Proses pembelajaran dilaksanakan dalam alur rutinitas, materi pemfaktoran disajikan dalam bahasan prosedural dan rumusan final, dan guru belum memanfaatkan media/alat. Proses pembelajaran yang demikian menyebabkan pemahaman dan penguasaan konsep lemah sehingga menyebabkan kesalahan dalam menyelesaikan pemfaktoran kuadrat sebagaimana ditunjukkan Gambar 1.
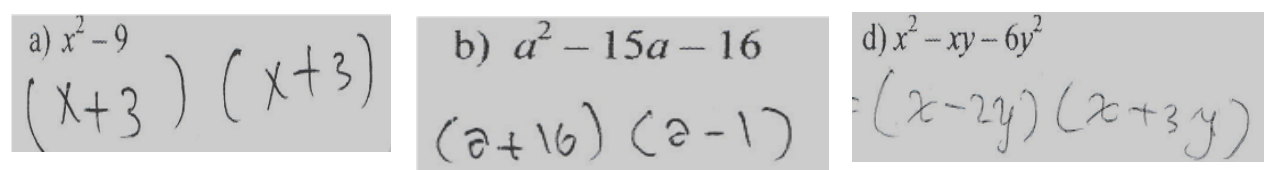

Gambar 1. Kesalahan Siswa Menyelesaikan Pemfaktoran Kuadrat

Untuk mengatasi permasalahan yang terjadi di kelas VIII G SMP Negeri 1 Jepara dan meningkatkan kualitas proses pembelajaran matematika, guru perlu melakukan perbaikan proses pembelajaran. Di antara langkah yang dapat dilakukan guru adalah merencanakan pembelajaran yang dapat melibatkan aktivitas siswa dan pemilihan dan pemanfaatan media/alat pembelajaran yang tepat dan sesuai dengan materi pemfaktoran kuadrat. Pemanfaatan media/alat pembelajaran yang tepat dan sesuai dengan materi matematika dan tingkat berpikir siswa sangat penting selama pembelajaran matematika. Hal ini didasarkan pada beberapa alasan, yaitu: (1) dapat mengembangkan sikap menguntungkan ke arah berpikir matematika, dan memudahkan abstraksi (Arsyad, 2011); (2) terciptanya kondisi belajar mengajar efektif dan dinamis (Hamzah \& Muhlisrarini, 2014: 97); (3) akan mempermudah pemahaman materi abstrak (Orton, 2006); dan (4) akan memudahkan pemahaman konsep aljabar (Toh, 2010).

Diharapkan dengan pemanfaatan Tabel $3 X 3$ selama proses pembelajaran pada konsep pemfaktoran kuadrat, semua siswa kelas VIII $G$ dapat aktif dan konstruktif beraktivitas matematis secara dinamis dengan cara mencoba-coba, menduga-duga, mengkomunikasikan ide dan gagasan matematis dengan mengonstruksi dan menyelesaikan berbagai 
soal pemfaktoran kuadrat. Selain itu, siswa dilatih bekerjasama dan berdiskusi antar siswa dengan tujuan memahami materi dan menyelesaikan soal/permasalahan pemfaktoran kuadrat yang diberikan sehingga siswa akan dapat memahami konsep pemfaktoran kuadrat secara mendalam, menyeluruh dan tidak cepat lupa yang dapat digunakan untuk menyelesaikan permasalahan.

Tabel 3X3 dalam penelitian ini dimanfaatkan untuk membelajarkan konsep pemfaktoran kuadrat dengan 3 bentuk umum, yaitu (1) $a x^{2} \pm b x \pm c$, dengan $a= \pm 1$; (2) $(a x)^{2}-c^{2}$, dengan $b=0$; dan (2) $a x^{2}$ $\pm b x \pm c$, dengan $a \quad \pm 1$. Tabel $3 X 3$ terdiri 3 kolom dan 3 baris. Bentuk Tabel $3 X 3$, petunjuk dan aturan Tabel 3 X3 untuk pemfaktoran kuadrat disajikan sebagai berikut.

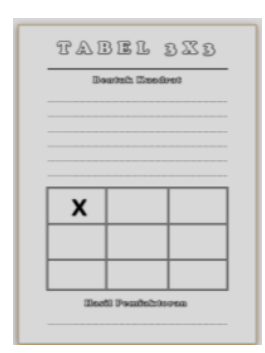

Tabel 3X3 dari Papan
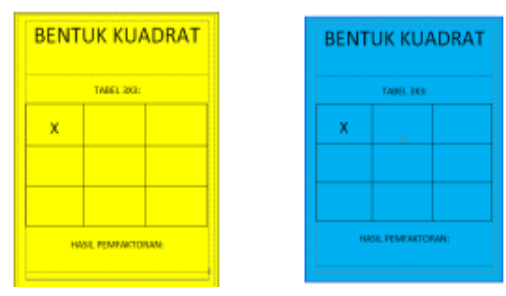

Tabel 3X3 terbuat Kertas Warna

\begin{tabular}{|c|c|c|}
\hline $\mathrm{X}$ & $\mathrm{K} 2$ & $\mathrm{~K} 3$ \\
\hline B2 & B2 $\times$ K2 & B2 $\times$ K3 \\
\hline B3 & B3 $\times$ K2 & B3 $\times$ K3 \\
\hline
\end{tabular}

Petunjuk pemanfaatan Tabel 3X3 :

1) Kalikan $B 2$ dengan $K 2$, menghasilkan $B 2 \times K 2$

2) Kalikan $B 3$ dengan $K 2$, menghasilkan $B 3 \times K 2$

3) Kalikan $B 2$ dengan $K 3$, menghasilkan $B 2 \times K 3$

4) Kalikan $B 3$ dengan $K 3$, menghasilkan $B 3 \times K 3$

5) Jumlahkan B3 x K2 dan B2 x K3

6) Hasil pemfaktoran kuadrat adalah $B 2$ dengan $B 3$ dan $K 2$ dengan $K 3$ yaitu (B2 $\pm \mathrm{B} 3)(\mathrm{K} 2 \pm \mathrm{K} 3)$, atau sebaliknya; $\mathrm{K} 2$ dengan $\mathrm{K} 3$ dan $\mathrm{B} 2$ dengan $\mathrm{B} 3$ yaitu $(\mathrm{K} 2 \pm \mathrm{K} 3)(\mathrm{B} 2 \pm \mathrm{B} 3)$. 
Pemanfaatan Tabel $3 \times 3$ untuk menentukan hasil pemfaktoran kuadrat dengan 3 bentuk umum, yaitu (a) $a x^{2}+b x+c$, dengan $a=1$; (b) $(a x)^{2}-c^{2}$, dengan $b=0$; dan (c) $a x^{2}+b x+c$, dengan $a \overline{1}$ disajikan berikut.

1) Bentuk $a x^{2} \pm b x \pm c$, dengan $a= \pm 1$

Faktorkanlah bentuk $x^{2}+3 x+2$, dengan $a=1$

\begin{tabular}{|c|c|c|}
\hline $\mathrm{X}$ & $x$ & 2 \\
\hline$x$ & $x^{2}$ & $2 x$ \\
\hline $\mathbf{1}$ & $x$ & $\mathbf{2}$ \\
\hline
\end{tabular}

Jadi bentuk pemfaktoran $x^{2}+3 x+2=(x+1)(x+2)$ atau $(x+2)(x+1)$

2) Bentuk $(a x)^{2}-c^{2}$, dengan $b=0$

Faktorkanlah bentuk $x^{2}-4$, dengan $b=0$

\begin{tabular}{|c|c|c|}
\hline $\mathrm{X}$ & $x$ & -2 \\
\hline$x$ & $x^{2}$ & $-2 x$ \\
\hline 2 & $2 x$ & -4 \\
\hline
\end{tabular}

Jadi bentuk pemfaktoran $x^{2}-4=(x+2)(x-2)$ atau $(x-2)(x+2)$

3) Bentuk $a x^{2}+b x+c^{2}$, dengan $a \overline{0}$

Faktorkanlah bentuk $2 x^{2}+5 x+3$

\begin{tabular}{|c|c|c|}
\hline $\mathrm{X}$ & $x$ & 1 \\
\hline $2 x$ & $2 x^{2}$ & $2 x$ \\
\hline 3 & $3 x$ & 3 \\
\hline
\end{tabular}

$2 x^{2}+3 x+2 x+3=2 x^{2}+5 x+3$

Jadi bentuk pemfaktoran $2 x^{2}+5 x+3=(2 x+3)(x+2)$ atau $(x+2)(2 x+3)$

Secara matematis, Tabel $3 \times 3$ tersebut dapat dimanfaatkan untuk pemfaktoran kuadrat 3 bentuk umum dan hasilnya, yaitu (1) $a x^{2}+b x+c$, dengan $a= \pm 1$, yaitu $(x+p)(x+q)$, dengan $p+q=b$ dan $p x q=c ;(2)(a x)^{2}-$ 
$c^{2}$, dengan $b=0$, yaitu $(x+p)(x-q)$; dan (3) $a x^{2}+b x+c$, dengan $a \overline{1}$ yaitu $(x+p)(x+q)$, dengan $p+q=b$ dan $p x q=a c$.

Pemanfaatan Tabel 3X3 dalam pembelajaran materi pemfaktoran kuadrat dengan fasilitasi guru, siswa dapat leluasa mencoba-coba, menduga-duga, menyelidiki, dan mengomunikasikan ide dan gagasan matematis dengan mengosntruksi pengetahuan dan pengalaman yang telah diperoleh siswa. Jadi, pada akhirnya siswa akan menemukan sendiri, memperoleh dan memahami bagaimana tentang konsep pemfaktoran kuadrat secara mendalam dan tidak cepat lupa yang pada akhirnya akan dapat meningkatkan pemahaman konsep pemfaktoran kuadrat sehingga akan meningkatkan prestasi belajar siswa.

Tujuan penelitian ini yaitu (1) mendeskripsikan pembelajaran dengan pemanfaatan Tabel 3X3 sehingga dapat meningkatkan pemahaman konsep pemfaktoran kuadrat siswa kelas VIII G SMP Negeri 1 Jepara, dan (2) mengetahui besar peningkatan pemahaman konsep pemfaktoran kuadrat dengan pemanfaatan Tabel 3X3 siswa kelas VIII G SMP Negeri 1 Jepara. Diharapkan dengan pemanfaatan Tabel 3X3 berdampak meningkatnya kualitas proses pembelajaran matematika, meningkatkan aktivitas dan berpikir matematis siswa, dan memudahkan siswa memahami konsep pemfaktoran kuadrat sehingga akan meningkatkan prestasi belajar.

\section{B. Metode}

Jenis penelitian ini adalah penelitian tindakan kelas (Classroom Action Research). Tindakan yang dilakukan guru sebagai peneliti disebut siklus. Rangkaian urutan dan tahapan setiap siklus meliputi: perencanaan (planning), tindakan (acting), observasi (observing), dan refleksi (reflecting) (Arikunto, 2013). Subjek penelitian ini adalah siswa kelas VIII G SMP Negeri 1 Jepara berjumlah 36 siswa. Prosedur dan alur penelitian tindakan kelas ini disajikan berikut. 


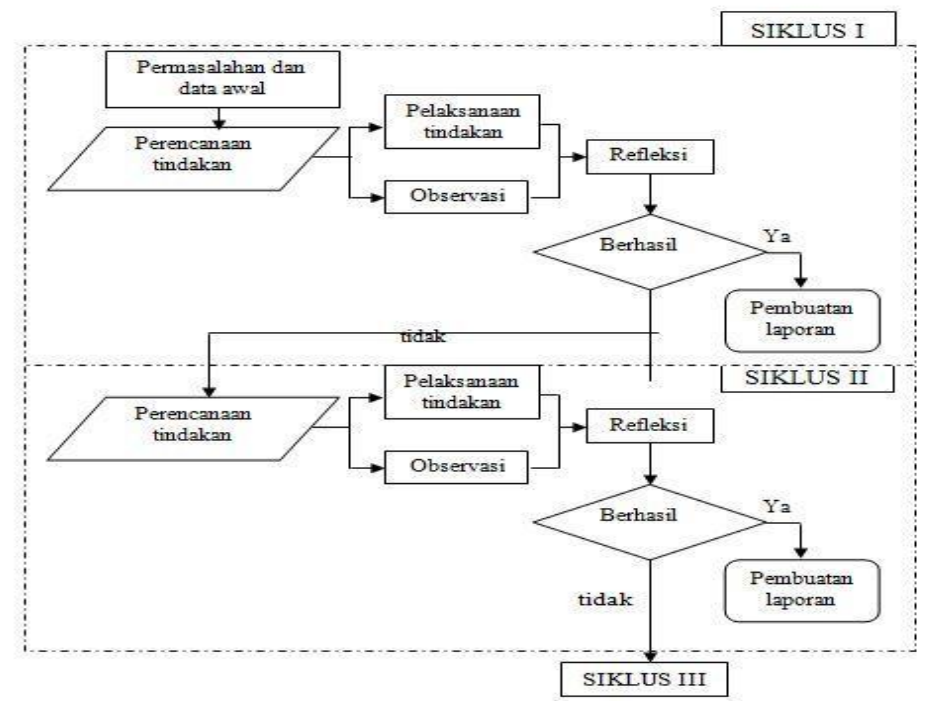

Gambar 1. Alur dan Prosedur Penelitian Tindakan Kelas

Instrumen penelitian, data penelitian dan sumber data dalam penelitian ini disajikan sebagai berikut.

Tabel 1. Instrumen, Data dan Sumber Data Penelitian

\begin{tabular}{|c|c|l|l|}
\hline No. & Instrumen & \multicolumn{1}{|c|}{ Data } & \multicolumn{1}{c|}{ Sumber Data } \\
\hline 1. & Lembar Observasi & $\begin{array}{l}\text { Hasil observasi aktivitas } \\
\text { guru }\end{array}$ & $\begin{array}{l}\text { Lembar observasi } \\
\text { aktivitas guru }\end{array}$ \\
\cline { 3 - 4 } & $\begin{array}{l}\text { Hasil observasi aktivitas } \\
\text { siswa }\end{array}$ & $\begin{array}{l}\text { Lembar observasi } \\
\text { aktivitas siswa }\end{array}$ \\
\hline 2. & $\begin{array}{c}\text { Lembar Catatan } \\
\text { Lapangan }\end{array}$ & $\begin{array}{l}\text { Catatan peristiwa yang } \\
\text { tidak tercantum pada } \\
\text { lembar observasi }\end{array}$ & $\begin{array}{l}\text { Lembar catatan } \\
\text { lapangan }\end{array}$ \\
\hline 3. & Perangkat Tes & Hasil/jawaban tes & $\begin{array}{l}\text { Lembar } \\
\text { jawaban siswa }\end{array}$ \\
\hline
\end{tabular}

Pada tahap perencanaan (planning), tindakan guru meliputi (1) mendesain RPP dan LKS; (2) menyiapkan Tabel 3X3; (3) membentuk kelompok diskusi beranggotakan 3 - 5 siswa berkemampuan heterogen (tinggi, sedang, rendah) berdasarkan nilai akademi dan jenis kelamin berbeda; (4) membuat Lembar Observasi Aktivitas Guru dan Siswa; (5) membuat Lembar Catatan Lapangan; dan (6) membuat perangkat tes. 
Pada tahap tindakan (acting), guru melaksanakan proses pembelajaran dengan pemanfaatan Tabel 3 X3 sesuai dengan RPP. Selama pembelajaran berlangsung, dilakukan observasi (observing) oleh guru matematika lain. Observer mengisi instrumen penelitian meliputi Lembar Observasi Aktivitas Guru dan Siswa, dan Lembar Catatan Lapangan terhadap aktivitas yang tidak belum tercantum pada Lembar Aktivitas Guru dan Siswa.

Tahapan refleksi (reflecting) dilakukan oleh guru dan observer. Tujuan refleksi adalah memahami, menjelaskan, menyimpulkan data hasil penelitian yang dapat digunakan untuk perencanaan dan perbaikan tindakan berikutnya. Acuan data penelitian yang digunakan pada tahap refleksi adalah hasil lembar observasi aktivitas guru dan siswa, hasil lembar catatan lapangan, dan skor jawaban tes siswa.

Untuk menghindari data bias, maka dilakukan pengecekan data penelitian. Pengecekan keabsahan data penelitian yang telah diperoleh menggunakan teknik pengecekan dengan kriteria derajat kepercayaan yang dilakukan dengan tiga cara, yaitu (1) ketekunan pengamatan, (2) triangulasi, dan (3) pengecekan teman sejawat (Moleong, 2014: 327-332).

Data penelitian dianalisis secara deskriptif. Data penelitian yang dianalisis meliputi (1) hasil observasi dalam Lembar Observasi Aktivitas Guru; (2) hasil observasi dalam Lembar Observasi Aktivitas Siswa; (3) catatan peristiwa yang tidak tercantum pada lembar observasi; dan (4) hasil/jawaban tes pemahaman konsep pemfaktoran kuadrat siswa kelas VIII G SMP Negeri 1 Jepara.

Analisis terhadap aktivitas guru dan siswa selama pembelajaran dengan pemanfaatan Tabel 3X3 mengacu pada Tabel 2. Nilai tes pemahaman konsep pemfaktoran kuadrat dianalisis berdasarkan skor/nilai rata-rata, nilai tertinggi, nilai terendah, dan ketuntasan belajar siswa individual yang mengacu pada KKM (Kriteria Ketuntasan Minimal) yang ditetapkan yaitu 75 . 
Tabel 2. Kriteria Aktivitas Guru dan Siswa

\begin{tabular}{|c|c|c|}
\hline No. & Interval & Keterangan \\
\hline 1. & $80<x \delta 100$ & Baik Sekali \\
\hline 2. & $60<x \delta 80$ & Baik \\
\hline 3. & $40<x \delta 60$ & Cukup Baik \\
\hline 4. & $21<x \delta 40$ & Kurang Baik \\
\hline 5. & $0<x \delta 20$ & Sangat Kurang Baik \\
\hline
\end{tabular}

(Sumber: Sahertian, 2010:60)

Penelitian ini dikatakan berhasil apabila memenuhi tiga indikator keberhasilan penelitian, yaitu (1) hasil aktivitas guru dan siswa minimal dengan kriteria baik (skor $60 \leq x \leq 80$ ); (2) skor tes siswa menunjukkan sekurang-kurangnya 70\% siswa mencapai skor minimal 75; dan (3) terjadi peningkatan rata-rata skor tes dari siklus sebelumnya ke siklus selanjutnya, misalkan dari kategori kurang baik meningkat menjadi cukup baik atau di atasnya, dan seterusnya.

\section{Hasil dan Pembahasan}

Penelitian ini dilakukan sebanyak 2 siklus. Pelaksanaan siklus I sebanyak 3 kali pembelajaran. Pembelajaran pertama membahas pemfaktoran kuadrat bentuk $a x^{2} \pm b x \pm c$, dengan $a=$ $\pm 1^{\mathrm{ax}} \pm \mathrm{bx} \pm \mathrm{c}$ dengan $\mathrm{a}= \pm 1 \mathrm{ax}{ }^{2} \pm \mathrm{bx} \pm \mathrm{c}$ dengan $\mathrm{a}= \pm 1$, pembelajaran kedua membahas pemfaktoran kuadrat bentuk $(a x)^{2}$ $c^{2}(\mathrm{ax})^{2}-\mathrm{c}^{2}(\mathrm{ax})^{2}-\mathrm{c}^{2}$ dengan $\mathrm{b}=0 \mathrm{~b}=0 \quad b=0$, dan pembelajaran ketiga membahas penerapan konsep pemfaktoran kuadrat untuk pemecahan masalah. Langkah pembelajaran dengan pemanfaatan Tabel 3X3 mengacu sintak pembelajaran kooperatif (Suprihatiningrum, 2014) sebagai berikut.

\section{Penyajian Informasi}

Pada tahapan ini, guru menyajikan informasi terkait dengan tujuan, teknik dan materi yang akan dipelajari siswa. Guru juga dapat 
pemberian soal prasyarat atau pembahasan tugas dengan tujuan untuk mengetahui kemampuan dasar siswa.

Guru : Bagaimana kabarnya semua?

Siswa : Baik Pak.

Guru : Baiklah, untuk beberapa pertemuan mendatang, kita semua akan

Siswa YaPak.

Pertemuan hari ini, kita akan membahas materi pemfaktoran

Guru : $\quad \begin{aligned} & \text { kuadrat yaitu } a^{2} \pm b x \pm c \text {, dengan } a= \pm 1 \\ & \text { (Guru menuliskan } a^{2} \pm b x \pm c \text {, dengan } a= \pm 1 \text { ) }\end{aligned}$

$\mathrm{ax}^{2} \pm \mathrm{bx} \pm \mathrm{c}$ dengan $\mathrm{a}= \pm 1 \mathrm{ax}^{2} \pm \mathrm{bx} \pm \mathrm{c}$ dengan $\mathrm{a}= \pm 1$

Guru : Baik, untuk perlengkapan belajar, buku tulis dan buku paket

matematika sudah siap ya?

Siswa : Ya Pak.

(Guru berkeliling memantau persiapan belajar siswa)

Bagus, untuk teknik pembelajaran hari ini kalian semua akan berkelompok 3-5 siswa guna berdiskusi membahas dan mengerjakan

Guru LK yang telah saya siapkan. Setiap kelompok akan mendapatkan LKS dan Tabel 3X3,

Siswa : YaPak. (Guru menyajikan Tabel 3X3 di depan kelas)

Berdasarkan dialog tersebut menunjukkan bahwa secara umum siswa telah siap mengikuti proses pembelajaran, dan siswa telah mengetahui rencana, teknik, dan tujuan pembelajaran yang akan dilakukan.

\section{Pembentukan Kelompok}

Pada tahap ini, guru memandu setiap siswa untuk berkelompok yang beranggotakan 3-5 siswa yang telah ditentukan berdasarkan kemampuan heterogen dan jenis kelamin yang berbeda. Selanjutnya guru membagi LKS dan Tabel 3X3 pada setiap kelompok dan menjelaskan petunjuk LKS dan teknik penggunaan/pemanfaatan Tabel 3X3 melalui contoh soal pemfaktoran kuadrat. 


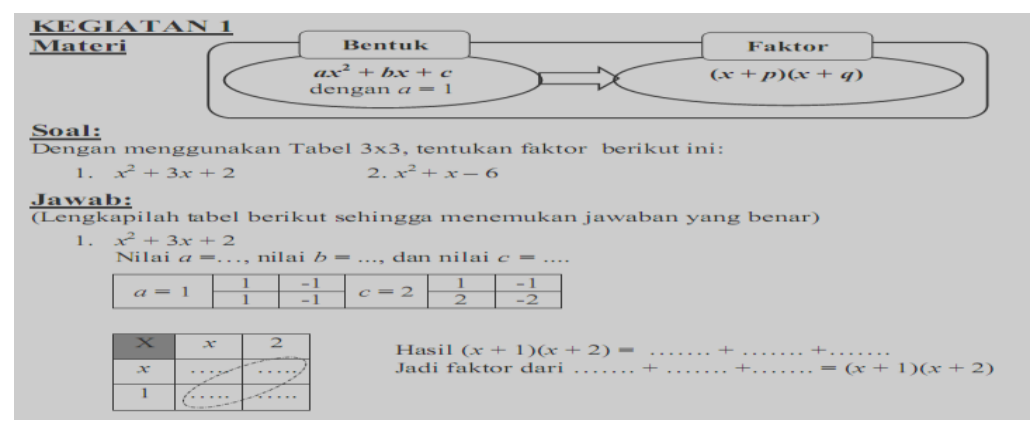

Gambar 2. LKS Pemfaktoran Kuadrat bentuk $a x^{2}+b x+c$ dengan $a=1$

\section{Diskusi Kelompok dan Bimbingan}

Kegiatan diskusi dilakukan setiap kelompok untuk memahami, menjawab dan menyelesaikan soal-soal pemfaktoran kuadrat di LKS melalui pemanfaatan Tabel 3X3. Selama proses diskusi kelompok, guru memantau aktivitas siswa dan memberikan scaffolding baik secara klasikal, kelompok atau kepada siswa yang mengalami kesulitan dengan memberi pertanyaan yang spesifik terhadap soal atau pertanyaan soal.

Siswa : Pak tanya!

(Kelompok 4)

Guru : Ya tanya tentang apa?

Siswa : Soal kegiatan 1: $x^{2}-4$. Baik perhatikan ke depan.

(Guru menuliskan $(a x)^{2}-c^{2}, b=0$ di papan tulis)

Guru . Coba perhatikan soal nomor 1: $x^{2}-4$

: $\quad$ Guru menuliskan $\left.x^{2}-4\right)$

Coba berapa nilai $a, b$, dan $c$ dari soal di atas!

Siswa : $a=1, b=0$ dan $c=-4$ (menjawab serentak)

(Guru menuliskan $\mathrm{a}=1, \mathrm{~b}=0$ dan $\mathrm{c}=4$ di papan tulis.)

Guru : Jadi kemungkinan $a=1$ diperoleh dari $1 \times 1,-1 x(-1)$

Kemungkinan $c=-4$ diperoleh dari $1 x-4,2 x(-2),-2 x 2,-1 x 4$

Guru menulis $a$ dan $c$ di papan tulis.

Guru : Silakan nilai tersebut dicoba-coba dihitung dengan menggunakan

Siswa : Baik Pak.

Berdasarkan proses dialog menunjukkan setelah guru memberikan scaffolding, siswa mulai memahami pemfaktoran bentuk soal: $x^{2}-4$. Siswa 
juga memahami proses dan cara menentukan pemfaktoran kuadrat dengan memanfaatkan Tabel $3 X 3$ sehingga hasil pemfaktoran dari $x^{2}-4=(x+2)(x-2)$.

Berikut disajikan proses diskusi siswa dengan pemanfaatan Tabel 3X3, dan hasil selesaian pemfaktoran kuadrat.

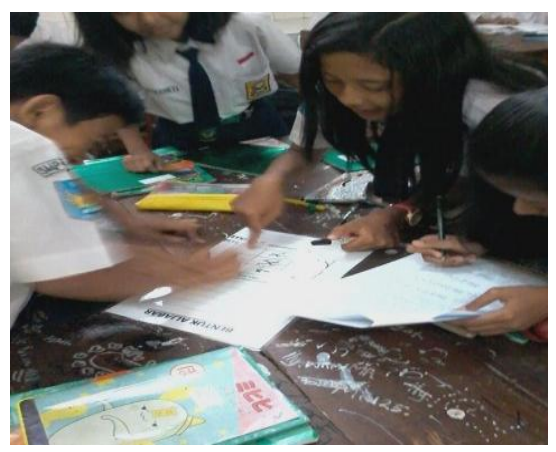

Gambar 3a. Diskusi Kelompok Menyelesaikan LKS

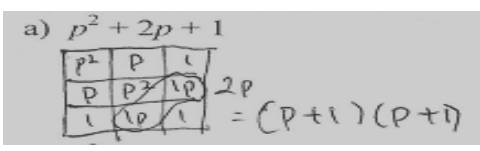

(a)

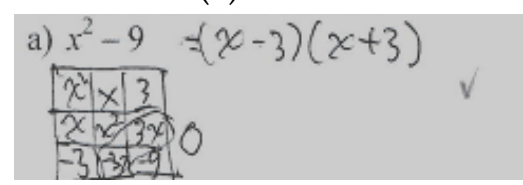

(c)

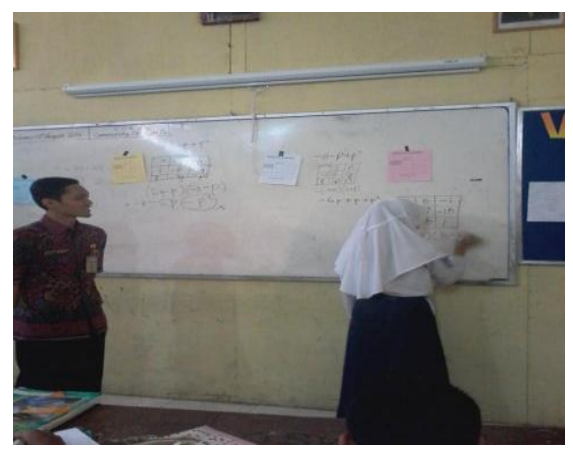

Gambar 3b. Siswa Menuliskan Jawaban Hasil Diskusi

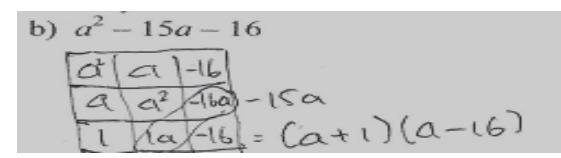

(b)

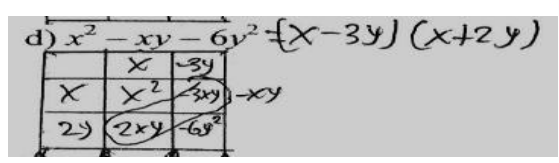

(d)

Gambar 4. Hasil Pemfaktoran Kuadrat dengan Pemanfaatan Tabel 3X3

Berdasarkan gambar $4 \mathrm{a}$ dan $4 \mathrm{~b}$ menunjukkan siswa mampu memfaktorkan kuadrat bentuk $a x^{2}+b x+c$ dengan $a=1$ melalui Tabel 3X3 dengan benar. Gambar $4 \mathrm{c}$ dan $4 \mathrm{~d}$ juga menunjukkan siswa mampu memfaktorkan kuadrat bentuk $(a x)^{2}-c^{2}$ dengan $b=1$ melalui Tabel 3X3 dengan benar. Proses jawaban menunjukkan siswa memahami konsep pemfaktoran kuadrat, mampu memilih dan menggunakan prosedur atau operasi tertentu untuk menyelesaikan soal pemfaktoran kuadrat dengan benar. Setelah diskusi kelompok, guru meminta dan menunjuk beberapa 
perwakilan kelompok menyajikan hasil diskusi dengan menuliskan jawaban di papan tulis. Selanjutnya guru meminta semua kelompok mengoreksi dan membandingkan jawaban yang disajikan kelompok lain dengan jawabannya sendiri. Jika ada jawaban yang berbeda, guru memberi kesempatan siswa/kelompok lain untuk menuliskan dan menyajikan penjelasan jawaban di papan tulis. Selanjutnya guru berdiskusi secara klasikal dengan semua kelompok membahas hasil jawaban soal tersebut, dan meminta siswa mengoreksi jawaban hasil diskusi.

\section{Pemberian Kuis dan Penghargaan}

Pemberian kuis dilakukan secara kelompok atau individu. Setelah pengerjaan kuis, selanjutnya dilakukan pembahasan jawaban kuis. Penghargaan diberikan kepada kelompok atau siswa yang paling aktif selama pembelajaran.

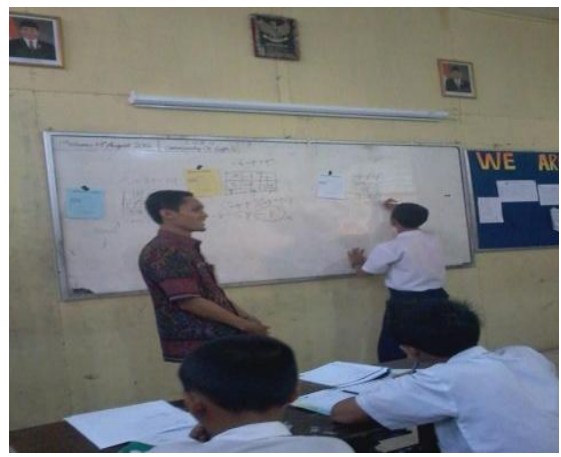

Gambar 5a. Siswa Menyajikan Jawaban Kuis

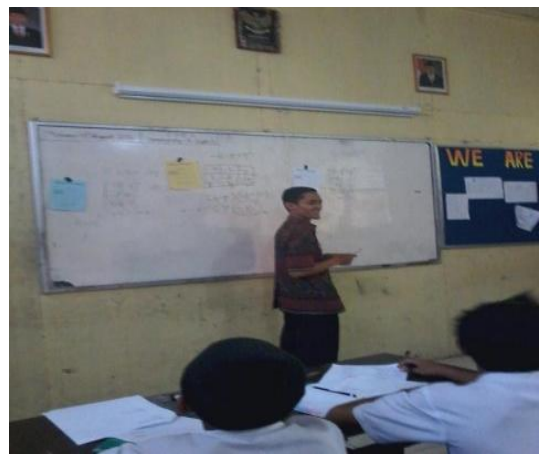

Gambar 5b. Guru Membahas Jawaban Kuis

\section{Penguatan konsep}

Pada tahap ini guru memberikan penguatan dan penjelasan tentang materi, konsep, aturan dan materi pemfaktoran kuadrat yang telah pelajari siswa. Selain itu, guru juga memberikan tugas mandiri kepada setiap siswa.

Setelah pembelajaran siklus I selesai, dilakukan tes siklus I dengan tujuan mengetahui kemampuan pemahaman konsep pemfaktoran kuadrat siswa. Selanjutnya, dilakukan refleksi hasil tindakan antara peneliti dan 
observer dengan menganalisis hasil 3 instrumen yaitu (1) lembar observasi aktivitas guru dan siswa; (2) hasil catatan lapangan; dan (3) skor hasil tes.

Hasil skor tes siklus I menunjukkan (a) nilai tertinggi 100, (b) nilai terendah 25,00, (c) nilai rata-rata 67,29 (kategori baik), dan (d) etercapaian nilai 75 hanya 58,33\%. Hasil refleksi siklus I menunjukkan bahwa kriteria keberhasilan penelitian belum terpenuhi semuanya. Berdasarkan hasil refleksi, penelitian perlu dilanjutkan siklus II dengan perbaikan tindakan guru, di antaranya (1) guru perlu menekankan kerjasama dan diskusi semua anggota kelompok; (2) guru perlu membentuk kelompok kecil 2 - 3 siswa agar diskusi semakin efektif dan dinamis; (3) penambahan banyaknya Tabel 3X3 sesuai jumlah kelompok; dan (4) dalam penyajian hasil diskusi, guru perlu menunjuk perwakilan kelompok secara merata terutama siswa yang berkemampuan rendah, pendiskusian, dan bimbingan.

Siklus II dilakukan sebanyak 2 kali pembelajaran. Pembelajaran keempat membahas materi pemfaktoran kuadrat bentuk $a x^{2} \pm b x \pm c$, dengan $a \quad-1^{a x^{2} \pm b x} \pm \mathrm{c}$ dengan $\mathrm{a}= \pm 1 \mathrm{ax}^{2} \pm \mathrm{bx} \pm \mathrm{c}$ dengan $\mathrm{a}= \pm 1$, dan pembelajaran kelima membahas penerapan konsep pemfaktoran kuadrat untuk menyelesaikan pemecahan masalah.
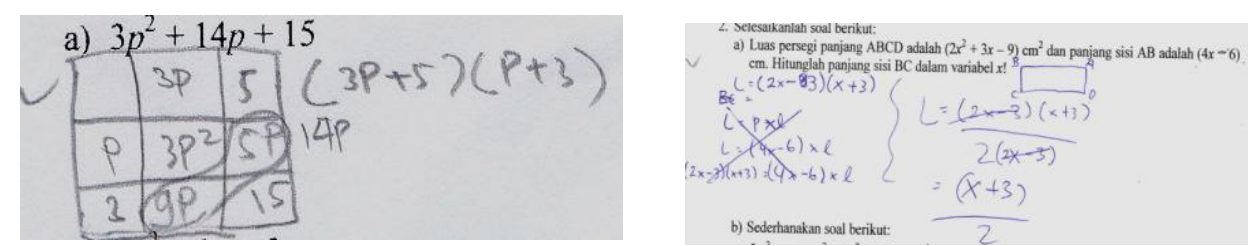

Gambar 6. Hasil Penyelesaian Pemfaktoran Kuadrat

Gambar 5 tersebut menunjukkan bahwa siswa telah mampu memilih dan menggunakan prosedur untuk menyelesaikan pemfaktoran kuadrat bentuk $a x^{2} \pm b x \pm c$, dengan $a^{-} \pm 1$ dengan Tabel 3X3 secara benar. Gambar 5 menunjukkan bahwa siswa mampu menyelesaikan soal cerita atau permasalahan dengan menggunakan konsep pemfaktoran kuadrat dengan benar. Penyelesaian pemfaktoran tersebut terkait indikator pemahaman konsep tentang kemampuan siswa menyelesaikan permasalahan dengan benar.

Hasil observasi aktivitas guru dan siswa selama pembelajaran dengan pemanfaatan Tabel 3X3 materi pemfaktoran kuadrat pada siklus I 
(P1, P2 dan P3) dan siklus II disajikan berikut ini.

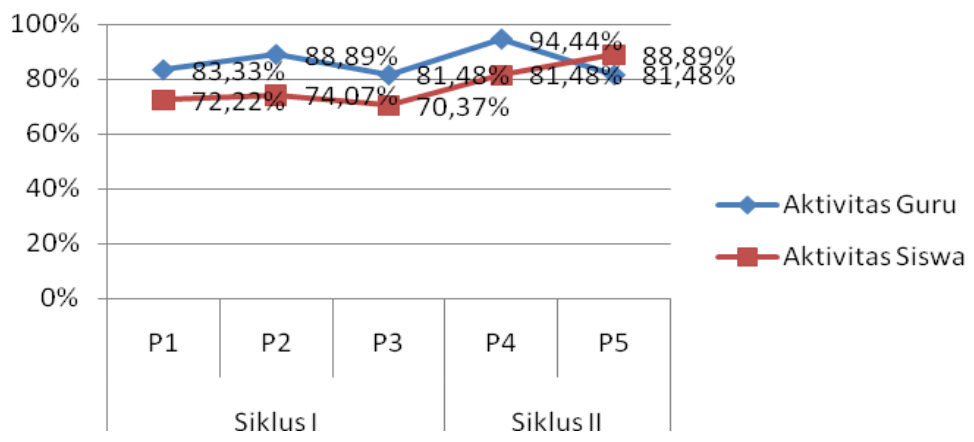

\section{Gambar 7. Persentase Aktivitas Guru dan Siswa Siklus I dan Siklus II}

Secara berurutan skor hasil observasi aktivitas guru dan siswa pembelajaran pertama (P1) adalah 83,33\% (kriteria baik sekali) dan 72,22\% (kriteria baik); pembelajaran kedua (P2) adalah 88,89\%(kriteria baik sekali) dan 74,07\% (kriteria baik); pembelajaran ketiga (P3) adalah 81,48\% (kriteria baik sekali) dan 70,37\% (kriteria baik); pembelajaran keempat (P4) adalah 94,44\% (kriteria baik sekali) dan 81,48\% (kriteria baik sekali); dan pembelajaran kelima adalah 98,15\% (kriteria baik sekali) dan 88,89\% (kriteria baik sekali). Secara keseluruhan skor aktivitas guru dan siswa selama pembelajaran dengan pemanfaatan Tabel 3X3 dengan kriteria baik.

\section{Skor Hasil Tes}

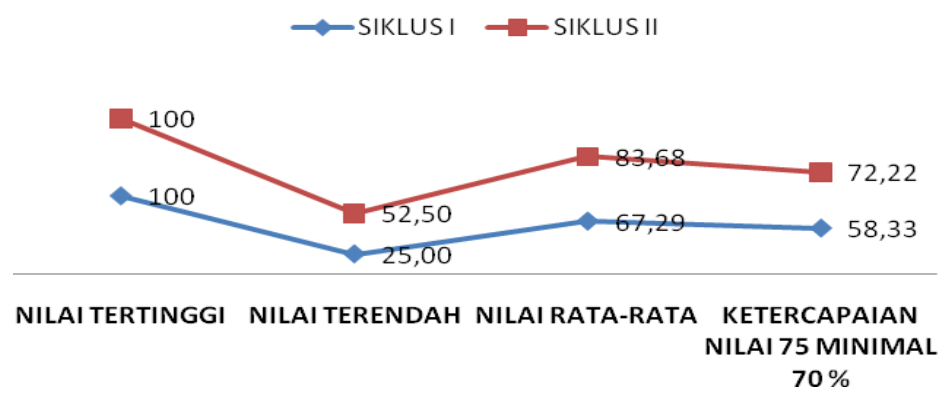

\section{Gambar 8. Skor Hasil Tes Siklus I dan Siklus II}

Gambar 8 menunjukkan bahwa hasil tes pemahaman konsep pemfaktoran kuadrat pada siklus I diperoleh nilai tertinggi 100, nilai 
terendah 25,00, nilai rata-rata 67,29 (kategori baik), dan ketercapaian nilai 75 hanya 58,33\%. Pada siklus II diperoleh nilai tertinggi 100, nilai terendah 52,50, nilai rata-rata 83,68 (kategori sangat baik), dan ketercapaian nilai 75 mencapai $72,22 \%$. Ini berarti siklus II telah memenuhi indikator keberhasilan penelitian minimal $70 \%$. Hasil ini menunjukkan dua indikator adanya peningkatan nilai rata-rata 67,29 pada siklus I menjadi 83,68 pada siklus II dan ketercapaian nilai 75 yaitu dari 58,33\% pada siklus I menjadi 72,22\% pada siklus II.

Berdasarkan data aktivitas guru dan siswa, dan hasil tes di atas tampak bahwa semua kriteria keberhasilan penelitian yang ditentukan telah terpenuhi semuanya yaitu (1) hasil observasi aktivitas guru dan siswa pada setiap pelaksanaan pembelajaran minimal dengan kriteria baik; (2) terdapat $72,22 \%$ siswa mampu mencapai skor minimal 75 dengan rata-rata skor 83,68; dan (2) peningkatan rata-rata skor hasil tes sebesar 16,39 atau $24,38 \%$ pada akhir siklus, dari kategori baik pada siklus I meningkat menjadi kategori sangat baik pada siklus II.

Hasil penelitian ini menunjukkan bahwa pemanfaatan Tabel 3×3 dapat meningkatkan pemahaman konsep pemfaktoran kuadrat siswa kelas VIII G SMP Negeri 1 Jepara. Pemanfaatan media pembelajaran matematika yang sesuai dengan materi dan tingkat berpikir siswa akan memberikan stimulus sehingga siswa aktif-konstruktif matematis secara dinamis yang melibatkan berbagai konsep matematis dan pengalaman siswa yang telah dimiliki sebelumnya. Siswa juga dapat bekerja sama, berdiskusi, berani mencoba, menduga-duga, mengkomunikasikan ide dan gagasan matematis dengan mengonstruksi serta menyelesaikan berbagai soal dan permasalahan pemfaktoran kuadrat. Kondisi yang demikian sejalan dengan Hudojo (2005: 83) yang menyatakan bahwa hakikat belajar matematika sebagai suatu proses mengonstruksi berbagai konsep dan prinsip matematika yang pasti melibatkan berbagai struktur hirarki dari konsep tingkat lebih tinggi atas dasar yang telah terbentuk sebelumnya. 
Pemanfaatan media yang sesuai dengan materi matematika juga akan dapat menjadikan pembelajaran berhasil guna dan berdaya guna (Prihatin, 2008: 48). Hal ini juga sejalan dengan pendapat Marshall \& Swan (2008) bahwa keuntungan penggunaan media bagi guru matematika akan membantu siswa untuk terlibat dalam pembelajaran yang aktif dan memberikan kesenangan bagi siswa.

\section{Penutup}

Berdasarkan paparan hasil penelitian dapat disimpulkan bahwa tahapan pembelajaran dengan pemanfaatan Tabel $3 \times 3$ yang dapat meningkatkan pemahaman konsep pemfaktoran kuadrat siswa kelas VIII G SMP Negeri 1 Jepara, yaitu (1) penyajian informasi dan tujuan pembelajaran, (2) pembentukan kelompok diskusi dengan kemampuan heterogen, (3) bimbingan diskusi kelompok, (4) pemberian kuis dan penghargaan, dan (5) penguatan konsep pemfaktoran kuadrat.

Pemanfaatan Tabel 3X3 pada materi pemfaktoran kuadrat siswa kelas VIII G SMP Negeri 1 Jepara dapat mengembangkan aktivitas siswa, motivasi, minat, keberanian mengungkapkan ide dan gagasan matematis, kerjasama, kemampuan komunikasi matematis, dan mempermudah siswa dalam memahami konsep pemfaktoran kuadrat. Peningkatan pemahaman konsep pemfaktoran kuadrat ditinjau berdasarkan rata-rata skor tes sebesar 16,39 atau $24,38 \%$ pada akhir siklus yaitu dari rata-rata skor 67,29 pada siklus I naik menjadi 83,68 pada siklus II dan kenaikan ketercapaian nilai 75 yaitu dari $58,33 \%$ pada siklus I menjadi $72,22 \%$ pada siklus II.

Saran berdasarkan hasil penelitian ini adalah (1) guru hendaknya memanfaatkan media/alat pembelajaran matematika; (2) Tabel 3X3 dapat dimanfaatkan pembelajaran pemfaktoran kuadrat; (3) guru harus mampu mendesain LKS yang mampu memicu siswa berpikir matematis (doing mathematic); dan (4) selama diskusi guru perlu melakukan scaffolding dan pengawasan yang merata pada setiap kelompok. 
Agus Prianto

\section{Ucapan Terimakasih}

Terima kasih saya sampaikan kepada Bapak Kepala Sekolah, semua guru dan segenap karyawan SMP Negeri 1 Jepara, Jawa Tengah yang telah memberikan fasilitas dan bantuan sehingga penelitian tindakan kelas ini dapat diselesaikan dengan baik.

\section{Daftar Referensi}

Arikunto, S. (2013). Prosedur Penelitian: Suatu Pendekatan Praktik. Bandung: Rineka Cipta.

Arsyad, A. (2011). Media Pembelajaran. Jakarta: Raja Grafindo Perkasa.

Hamzah, A. \& Muhlisrarini, (2014). Perencanaan dan Strategi Pembelajaran Matematika. Jakarta: Rajagrafindo Indonesia.

Hudojo, H. (2005). Kapita Selekta Pembelajaran Matematika. Malang: UM Press.

Marshall, L., \& Swan, P. (2008). Exploring The Use of Mathematics Manipulative Materials : Is It What We Think It Is? EDU-COM International Conference:338-350.

Moleong, L.J. (2014). Metodologi Penelitian Kualitatif. (Cetakan 32). Bandung: Remaja Rosyda Karya.

Orton, A. (2006). Learning Mathematics: Issues, Theory and Classroom Practice (Third Edition). London: Continuum.

Prihatin, E. (2008). Guru Sebagai Fasilitator. Bandung: Karsa Mandiri Persada.

Rosalin, E. (2008). Gagasan Merancang Pembelajaran Kontekstual. Bandung: Karsa Mandiri Perkasa.

Sahertian, P.A. (2010). Konsep Dasar \& Teknik Supervisi Pendidikan: dalam Rangka Pengembangan Sumber Daya Manusia. Jakarta: Rineka Cipta.

Subanji. (2013). Pembelajaran Matematika Kreatif dan Inovatif. Malang: UM Press.

Subanji. (2015). Teori Kesalahan Konstruksi Konsep dan Pemecahan Masalah Matematika. Malang: UM Press. 
Suprihatiningrum, J. (2014). Strategi Pembelajaran: Teori \& Aplikasi. (Cetakan 2). Yogyakarta: Ar-Ruzz Media.

Tabrani ZA \& Murziqin, R. (2015). Political Education in Maturation Democracy in Indonesia. British Journal of Political Science, 45 (1), 215-226

Tabrani ZA. (2011). Dynamics of Political System of Education Indonesia. International Journal of Democracy, 17(2), 99-113.

Tabrani ZA. (2012). Future Life of Islamic Education in Indonesia. International Journal of Democracy, 18(2), 271-284.

The National Council of Teachers of Mathematics (NCTM). (2000). Principles and Standards for School Mathematics. United States of America: NCTM Inc.

Toh, L, T., (2010). Use of Cartoons and Comics to Teach Algebra in Mathematics Classrooms: 230-239. (Online) (http://www.mav.vic.edu.au/files/ conferences/2009/12Toh.pdf.) Diakses 10 Januari 2018.

Van de Walle, J.A., Karps, K.S. \& Bay-Wlliams, J.M. (2008). Elementary and Middle School Mathematics: Teaching Developmentally. USA: Allyn \& Bacon.

Yoong, W, K. (1987). Aspects of Mathematical Understanding. Singapore Journal of Education. 8(2):45-55.

Zerpa, C, Kajander, A \& Van Barneveld, C. (2009). Factors That Impact Preservice Teachers' Growth in Conceptual Mathematical Knowledge During A Mathematics Method Course. International Electronic Journal of Mathematics Education. 4(2):352-362. 